\title{
Kinetics and mechanism of the reaction between chromium (III) and diethylenetriaminepentaacetic acid
}

\author{
Samy Sophy Anis*, Zeinab Mohamed Abou-Gamra, Michel Fahmy Abdel-Messih, Eman Hassan \\ Abdel-Khalek
}

Chemistry Department, Faculty of Science, Ain Shams University, Abbassia, Cairo, Egypt

A R T I C L E I N F O

Article history:

Received 12 September 2011

Accepted 16 November 2011

Keywords:

Kinetics;

Substitution;

Complexation;

Chromium(III);

DTPA.

\section{A B S T R A C T}

The kinetics and mechanism of complex formation between chromium (III) and diethylenetriaminepentaacetic acid (DTPA) were studied spectrophotometrically in an aqueous acid medium over the temperature range of $35-50^{\circ} \mathrm{C}$ using large excess of the ligand. The reaction was found to be first - order in chromium (III) concentration and zero-order in DTPA concentration. The rate of reaction showed inverse dependence on hydrogen ion concentration. Values of $104 \mathrm{~kJ} \mathrm{~mol}^{-1}$ and 14 $\mathrm{JK}^{-1} \mathrm{~mol}^{-1}$ were obtained for enthalpy and entropy of activations, respectively. $\mathrm{I}_{\mathrm{d}}$ mechanism has been proposed based upon the release of water molecule from the active species $\left[\mathrm{Cr}\left(\mathrm{H}_{2} \mathrm{O}\right)_{5} \mathrm{OH}\right]^{2+}$ in a rate-determining step. The rate law has been established to be: rate $=\underline{\mathrm{kK}[\mathrm{Cr}(\mathrm{III})]_{\mathrm{T}}}$

$\left[\mathrm{H}^{+}\right]+\mathrm{K}$

\section{Introduction}

The essentiality of trace amounts of chromium(III) is well known [1,2]. In an active form, chromium functions to improve insulin biological activity.

Diethylenetriaminepentaacetic acid is commonly used as a strong chelating agent. It's used for decontamination of the heavy metal poising [3, 4] and exposition to radioactive metals [5]. In addition to their chelating properties they influence inflammatory diseases [6], reduce the side effects of some chemotherapeutics therapy in cancer [7]. The kinetics of complex formation between chromium (III) ion and L-histidine [8], aminopyridine [9], L-isoleucine [10] have been studied. In all cases the reaction proceeds by a path which is first - order in chromium (III) and the rate of reaction increases with increasing $\mathrm{pH}$ and temperature. The mechanism has been modeled involving outer-sphere complexation of a hexaaquachromium(III) and conjugate base with the amino acid. The tridentate amino acids such as cysteine, glutamic acid were predominantly found cross - linked to DNA [11]. The mechanism by which chromium (III) can cross - link these amino acids to DNA has been modeled by creating DNA and chromium (III) with cysteine. The formation of chromium (III) - amino acid binary complex was required before the reaction of chromium (III) with DNA to yield a ternary complex. The kinetics of the re-

\footnotetext{
* Corresponding author.

E-mail address: samyanis53@yahoo.com

Tel: +201224901011
}

action between chromium (III) and aminopolycarboxylate ligands $[12,13]$ which contain N, $\mathrm{O}$ donor centers have been studied and an associative mechanism has been proposed. In the present study, we discuss the kinetics and mechanism of $\mathrm{Cr}$ (III)-DTPA complex formation in aqueous acidic solution.

\section{Experimental}

The reagents used were all of analytical grade. DTPA is used as received, stock solution of DTPA $\left(0.1 \mathrm{~mol} \mathrm{~L}^{-1}\right)$ was prepared by dissolving the solid in dilute solution of $\mathrm{NaOH}$ and standardized against zinc solution using xylenol orange as indicator. The stock solution of chromium (III) was prepared and determined spectrophotometrically as chromate. The dinuclear complex was prepared by adding iron (III) ion to the Cr(III)-DTPA complex with ratio of 1:1. Spectrophotometric measurements were made to ensure complete formation of the complexes.

\section{Kinetic measurements}

All kinetic measurements were followed spectrophotometrically using Unicam Helios $\propto$ spectrophotometer equipped with a water-jacketed cell holder. The reactants were thermostated for ca-15 min then mixed thoroughly and quickly transformed to an absorption cell. The formation of the $\mathrm{Cr}$ (III)-DTPA complex was followed by monitoring the growth of absorbance at $\lambda_{\max }=550 \mathrm{~nm}$ as a function of time. 
Pseudo-first-order conditions were maintained in all runs by using a large excess of DTPA compared to chromium(III) solution. The $\mathrm{pH}$ of the reaction was measured using a Radiometer M 62 pH-meter fitted with a combined glass-calomel electrode. The ionic strength was adjusted at $0.2 \mathrm{~mol} \mathrm{~L}^{-1}$ using $\mathrm{NaNO}_{3}$ solution.

\section{Results and discussion}

The value of $\mathrm{pK}_{\mathrm{a}}$ for $\mathrm{Cr}\left(\mathrm{H}_{2} \mathrm{O}\right)_{6}{ }^{3+} / \mathrm{Cr}\left(\mathrm{H}_{2} \mathrm{O}\right)_{5} \mathrm{OH}^{2+}$ is 3.89 [14]. At pH below 4, chromium (III) exists mainly in its hexaaquamonomeric form. As the $\mathrm{pH}$ increases, the concentration of the hydroxopentaaquachromium(III) species increases and is considered to be the main reactive species which, in turn, increases the reaction rate. At $\mathrm{pH} 5$, the condensation of the two $\mathrm{Cr}\left(\mathrm{H}_{2} \mathrm{O}\right)_{5} \mathrm{OH}^{2+}$ gives the dimeric hydroxobridge species [15]. The $\mathrm{pK}$ values for the DTPA associated with the step-wise equilibria were determined to be $2.18,2.9$, 4.2, 8.64 and 9.87 for $\mathrm{n}=5,4,3,2$ and 1 respectively[16].

$$
\mathrm{H}_{\mathrm{n}} \mathrm{L} \stackrel{\mathrm{K}}{\rightleftharpoons} \mathrm{H}_{\mathrm{n}-1} \mathrm{~L}
$$

Under the present experimental conditions, the ligand exists mainly as $\mathrm{H}_{2} \mathrm{~L}^{3-}$. DTPA acts as a pentadentate ligand in its coordination leaving three sites promoting the formation of dinuclear complexes [17].

Solutions of chromium (III) give upon addition of DTPA in acidic aqueous solution an increase of absorption and the violet $\mathrm{Cr}$ (III)-DTPA complex exhibits maxima at 390 and $550 \mathrm{~nm}$ (Figure 1).

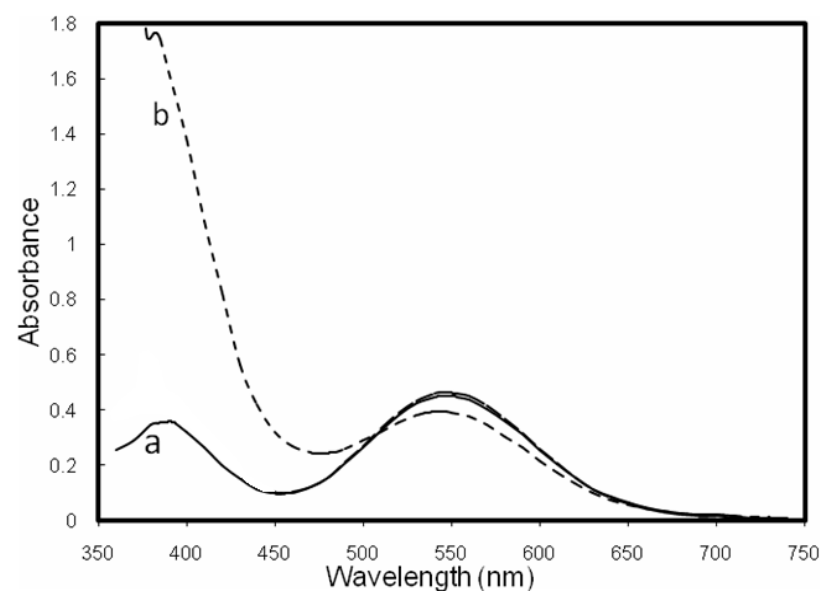

Fig. 1: Absorption spectra of: (a) Cr(III) DTPA, (b) Cr(III)DTPA with $\mathrm{Fe}(\mathrm{III}), \mathrm{pH}=2$.

The 1:1 Cr (III)-DTPA complex is a stable species, the chelation involves coordination of the two amine groups and three carboxylate groups leaving the iminodiacetate uncoordinated [17] (Figure 2).

Therefore Cr(III)-DTPA complex can form dinuclear mixed complexes with metal ions [18]. Addition of $\mathrm{Fe}$ (III) to the $\mathrm{Cr}$ (III)-DTPA complex results in a new red coloured complex which absorbs at 379 and $542 \mathrm{~nm}$ (Figure1) in which the iminodiacetate group behaves as a tridentate, chelating chromium (III) via two carboxylate and the amine groups.

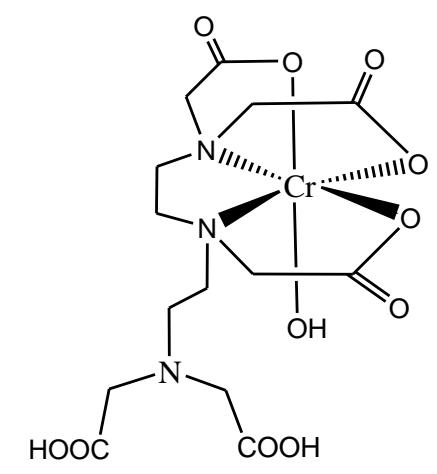

Fig. 2: Structure of the Cr(III) DTPA complex.

The kinetics of the complex formation were studied over the $\mathrm{pH}$ range 2.9-5.18 and temperatures 35, 40, 45 and $50^{\circ} \mathrm{C}$ over a range of ligand concentrations 0.040 $0.072 \mathrm{~mol} \mathrm{~L}^{-1}$. Pseudo-first order kinetics was maintained in all runs by using a large excess of ligand over the chromium (III) ion. Figure 3 presents examples of the first - order plots obtained for the formation of $\mathrm{Cr}(\mathrm{III})$ DTPA complex. Also included, for the sake of comparison, are the second - order plots for the same experiments.

Obviously, the first-order plots hold better at $\mathrm{pH} 3.8$, while at $\mathrm{pH} 4.98$, the second order plots were better which indicates that at higher $\mathrm{pH}$ values $(\mathrm{pH}>4.7)$, the dimeric chromium (III) exists. The observed rate constants obtained from the slopes of these plots are listed in Tables 1 and 2. Changing the initial chromium (III) concentration from $2.8 \times 10^{-3}$ to $5.2 \times 10^{-3} \mathrm{~mol} \mathrm{~L}^{-1}$ did not affect the observed first-order rate constants. The constancy of $k_{o}$ at various concentrations of chromium (III) confirms first-order dependence on the chromium (III) concentration. It follows,

$$
\text { Rate }=\frac{-\mathrm{d}[\mathrm{Cr}(\mathrm{III})]}{\mathrm{dt}}=\mathrm{k}_{\mathrm{o}}[\mathrm{Cr}(\text { III })]_{\mathrm{T}}
$$

Where $[\mathrm{Cr}(\mathrm{III})]_{\mathrm{T}}$ represents the total chromium (III) concentration.

When all experimental conditions were kept constant except the DTPA concentration, the rate of reaction is independent on its concentration. This indicates that the DTPA is not involved in the rate-determining step. The simplest interpretation of the data is that the formation of the chromium (III) complex occurs via a fast reaction between the reactive species of chromium (III) and the ligand. The data in Tables 1 and 2 indicate that the observed rate constants increase as the $\mathrm{pH}$ increases over the range studied. 
Table 1: $1^{\text {st }}$ order rate constants for reaction of $\left[\mathrm{Cr}\left(\mathrm{NO}_{3}\right)_{3}\right] .9 \mathrm{H}_{2} \mathrm{O}$ with DTPA at various $\mathrm{pH}$ and temperatures, $\left[\mathrm{Cr}\left(\mathrm{NO}_{3}\right)_{3}\right] .9 \mathrm{H}_{2} \mathrm{O}=4 \times 10^{-3} \mathrm{~mol} \mathrm{~L}^{-1}$.

\begin{tabular}{|c|c|c|c|}
\hline Temp. $\left({ }^{0} \mathrm{C}\right)$ & $\operatorname{DTPA}\left(\mathrm{mol} \mathrm{L}^{-1}\right)$ & pH & $k \times 10^{3}\left(s^{-1}\right)$ \\
\hline \multirow[t]{3}{*}{35} & 0.040 & 3.65 & 0.207 \\
\hline & 0.040 & 4.05 & 0.380 \\
\hline & 0.040 & 4.46 & 0.520 \\
\hline \multirow[t]{10}{*}{40} & 0.040 & 3.40 & 0.260 \\
\hline & 0.040 & 3.62 & 0.360 \\
\hline & 0.040 & 4.50 & 1.018 \\
\hline & 0.040 & 4.87 & 1.478 \\
\hline & 0.040 & $3.65^{\mathrm{a}}$ & 0.332 \\
\hline & 0.040 & $4.25^{\mathrm{a}}$ & 0.693 \\
\hline & 0.040 & $4.50^{\mathrm{a}}$ & 0.945 \\
\hline & 0.040 & $3.75^{\mathrm{b}}$ & 0.375 \\
\hline & 0.040 & $4.30^{\mathrm{b}}$ & 0.773 \\
\hline & 0.040 & $4.42^{\mathrm{b}}$ & 0.840 \\
\hline \multirow[t]{26}{*}{45} & 0.040 & 3.10 & 0.293 \\
\hline & 0.040 & 3.38 & 0.565 \\
\hline & 0.040 & 3.74 & 0.693 \\
\hline & 0.040 & 4.08 & 1.008 \\
\hline & 0.040 & 4.30 & 1.232 \\
\hline & 0.040 & 4.53 & 1.673 \\
\hline & 0.050 & 2.93 & 0.237 \\
\hline & 0.050 & 3.20 & 0.336 \\
\hline & 0.050 & 3.27 & 0.406 \\
\hline & 0.050 & 3.45 & 0.470 \\
\hline & 0.050 & 3.75 & 0.638 \\
\hline & 0.050 & 4.17 & 1.053 \\
\hline & 0.050 & 4.33 & 1.611 \\
\hline & 0.050 & 4.43 & 1.705 \\
\hline & 0.060 & 3.00 & 0.280 \\
\hline & 0.060 & 3.29 & 0.352 \\
\hline & 0.060 & 3.40 & 0.443 \\
\hline & 0.060 & 4.02 & 1.042 \\
\hline & 0.060 & 4.30 & 1.660 \\
\hline & 0.072 & 3.1 & 0.275 \\
\hline & 0.072 & 3.25 & 0.313 \\
\hline & 0.072 & 3.63 & 0.567 \\
\hline & 0.072 & 3.70 & 0.600 \\
\hline & 0.072 & 3.82 & 0.793 \\
\hline & 0.072 & 4.17 & 1.192 \\
\hline & 0.072 & 4.48 & 1.932 \\
\hline \multirow[t]{5}{*}{50} & 0.040 & 2.90 & 0.628 \\
\hline & 0.040 & 3.20 & 0.850 \\
\hline & 0.040 & 3.40 & 1.148 \\
\hline & 0.040 & 3.70 & 1.365 \\
\hline & 0.040 & 4.00 & 2.070 \\
\hline
\end{tabular}

${ }^{\mathrm{a}}\left[\mathrm{Cr}\left(\mathrm{NO}_{3}\right)_{3}\right] .9 \mathrm{H}_{2} \mathrm{O}=2.8 \times 10^{-3} \mathrm{M}$

${ }^{\mathrm{b}}\left[\mathrm{Cr}\left(\mathrm{NO}_{3}\right)_{3}\right] .9 \mathrm{H}_{2} \mathrm{O}=5.2 \times 10^{-3} \mathrm{M}$ 

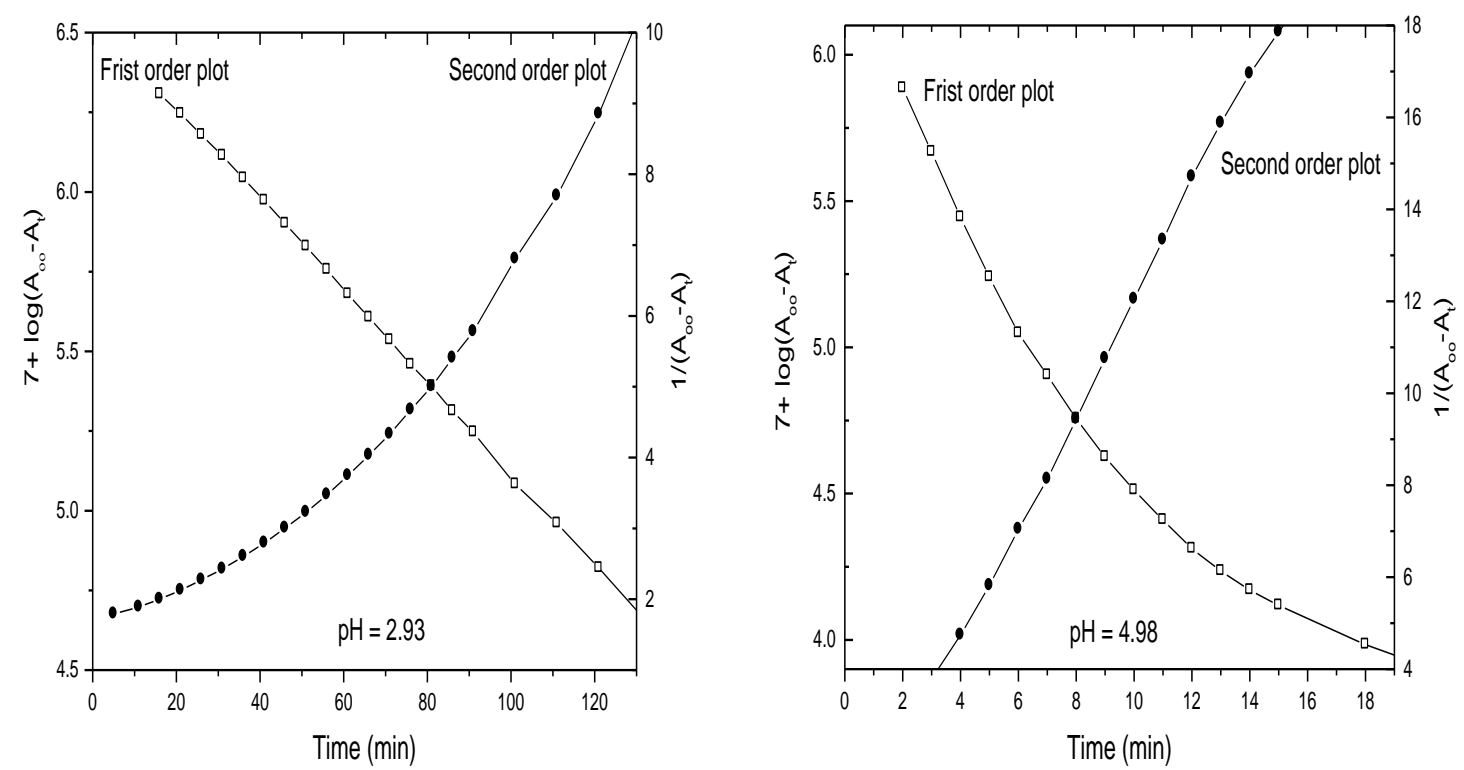

Fig. 3: Pseudo-first order plots and the corresponding second-order plots at $45^{\circ} \mathrm{C},[\mathrm{Cr}(\mathrm{III})]=4 \times 10^{-3} \mathrm{~mol} \mathrm{~L}^{-1}$, $[\mathrm{DTPA}]=0.04 \mathrm{~mol} \mathrm{~L}^{-1}$

Table 2: $2^{\text {nd }}$ order rate constants for reaction of $\left[\mathrm{Cr}\left(\mathrm{NO}_{3}\right)_{3}\right] .9 \mathrm{H}_{2} \mathrm{O}$ with DTPA at various $\mathrm{pH}$ and temperatures , $\left[\mathrm{Cr}\left(\mathrm{NO}_{3}\right)_{3}\right] .9 \mathrm{H}_{2} \mathrm{O}=4 \times 10^{-3} \mathrm{~mol} \mathrm{~L}^{-1}$.

\begin{tabular}{|c|c|c|c|}
\hline Temp. $\left({ }^{\circ} \mathrm{C}\right)$ & DTPA $\left(\mathrm{mol} \mathrm{L}^{-1}\right)$ & pH & $\operatorname{kx10}{ }^{3}\left(\mathrm{~L} \mathrm{~mol}^{-1} \mathrm{~s}^{-1}\right)$ \\
\hline 35 & 0.040 & 4.80 & 5.308 \\
\hline \multirow{2}{*}{40} & 0.040 & 4.87 & 10.10 \\
\hline & 0.040 & 4.75 & 11.82 \\
\hline \multirow[t]{13}{*}{45} & 0.040 & 4.98 & 19.94 \\
\hline & 0.040 & 5.08 & 15.11 \\
\hline & 0.040 & 5.18 & 18.76 \\
\hline & 0.040 & 5.23 & 20.33 \\
\hline & 0.050 & 4.70 & 14.62 \\
\hline & 0.050 & 4.80 & 20.42 \\
\hline & 0.050 & 5.06 & 25.16 \\
\hline & 0.050 & 5.14 & 36.75 \\
\hline & 0.050 . & 5.30 & 25.35 \\
\hline & 0.060 & 4.93 & 17.66 \\
\hline & 0.060 & 5.15 & 29.43 \\
\hline & 0.070 & 4.86 & 16.99 \\
\hline & 0.070 & 5.18 & 21.35 \\
\hline
\end{tabular}


Plots of $\mathrm{k}_{\mathrm{o}}^{-1}$ vs $\left[\mathrm{H}^{+}\right]$, at different temperatures, gave straight lines with non-zero intercepts as shown in Figure 4. In general, such a situation arises when one of the reactants is in equilibrium with its conjugate base and the latter is the only reactive species [19].

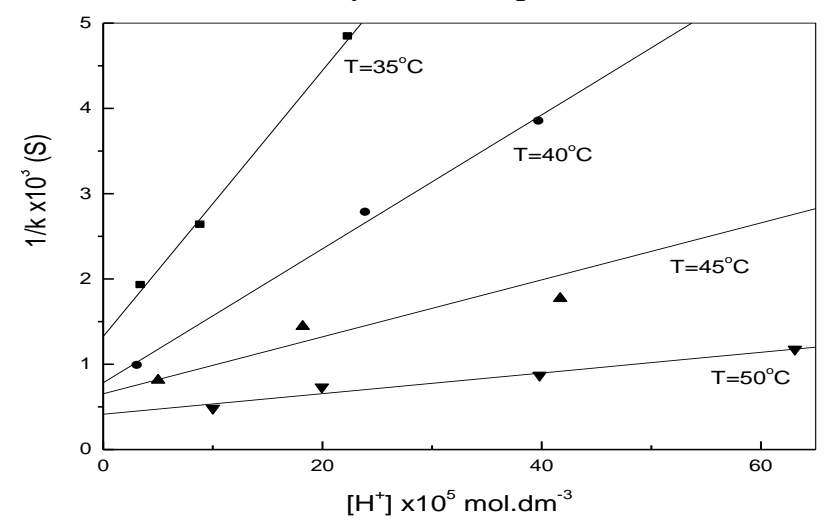

Fig. 4: The inverse dependency of the rate constants on the concentration of the hydrogen ion at various temperatures

In $\mathrm{Cr}\left(\mathrm{H}_{2} \mathrm{O}\right)_{5} \mathrm{OH}^{2+}$, the hydroxide ion facilitates the loss of water ligand by increasing the electron density at the metal center. Thus, easy rupture $\mathrm{Cr}-\mathrm{OH}_{2}$ bond favors the simultaneous rapid formation of the complex. Therefore the retardation of the observed rate constant by increasing hydrogen ion concentration was due to the protonation which occurs on the nitrogen atom of the ligand [20]. The formations of $\mathrm{N}-\mathrm{H}$ bond leads to strength the $\mathrm{Cr}-\mathrm{OH}_{2}$ bond and reduce the advantage of bond formation between chromium (III) and the ligand. Also protonation on nitrogen atom promotes hydrogen bonding between the carboxylate oxygen donors and protonated nitrogen atoms.

The overall mechanism of the reaction process can be represented by the release of water molecule in a ratedetermining step from the coordination sphere of the chromium (III) followed by insertion of the amino nitrogen of the ligand into the inner coordination sphere of the chromium (III) which results in increasing the electron density on the chromium (III) center through the inductive effect. As a result, the remaining water ligands are labialized very easily and subsequent substitution is rapid.

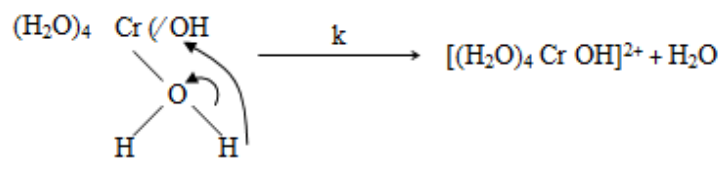

(slow)

$\left[\left(\mathrm{H}_{2} \mathrm{O}\right)_{4} \mathrm{Cr} \mathrm{OH}\right]^{2+}+\mathrm{H}_{2} \mathrm{~L}^{3-}$ $\left[\mathrm{Cr} \mathrm{H}_{2} \mathrm{LOH}\right]$
Based on these results, the following rate law is formulated,

$$
\begin{aligned}
& \text { Rate = k }\left[\mathrm{Cr}\left(\mathrm{H}_{2} \mathrm{O}\right)_{4} \mathrm{OH}^{2+}\right] \\
& \begin{aligned}
{[\mathrm{Cr}(\mathrm{III})]_{\mathrm{T}}=\left[\mathrm{Cr}\left(\mathrm{H}_{2} \mathrm{O}\right)_{6}{ }^{3+}\right]+\left[\mathrm{Cr}\left(\mathrm{H}_{2} \mathrm{O}\right)_{5} \mathrm{OH}^{2+}\right] } \\
=\left[\mathrm{Cr}\left(\mathrm{H}_{2} \mathrm{O}\right)_{5} \mathrm{OH}^{2+}\right]\left\{\frac{\left[\mathrm{H}^{+}\right]}{\mathrm{K}}+1\right\}
\end{aligned}
\end{aligned}
$$

where $\mathrm{K}$ is the ionization constant for the reaction

$$
\mathrm{Cr}\left(\mathrm{H}_{2} \mathrm{O}\right)_{6}{ }^{3+} \leftrightarrows \mathrm{Cr}\left(\mathrm{H}_{2} \mathrm{O}\right)_{5} \mathrm{OH}^{2+}+\mathrm{H}^{+}
$$

and $\mathrm{k}$ is the rate constant for the release of water molecule from $\mathrm{Cr}\left(\mathrm{H}_{2} \mathrm{O}\right)_{5} \mathrm{OH}^{2+}$

$$
\begin{aligned}
& \therefore\left[\mathrm{Cr}\left(\mathrm{H}_{2} \mathrm{O}\right)_{5} \mathrm{OH}^{2+}\right]=\frac{\mathrm{K}[\mathrm{Cr}(\mathrm{III})]_{\mathrm{T}}}{\left[\mathrm{H}^{+}\right]+\mathrm{K}} \\
& \text { Rate }=\frac{\mathrm{kK}[\mathrm{Cr}(\mathrm{III})]_{\mathrm{T}}}{\left[\mathrm{H}^{+}\right]+\mathrm{K}} \\
& \text { and } \mathrm{k}_{0}=\frac{k K}{\left[H^{+}\right]+K}
\end{aligned}
$$

This mechanism differs from that proposed for the complex formation of chromium (III) and polyaminocarboxylic acids [12,13]. In the latter cases, the reaction proceeds through fast formation of the ionpair intermediate followed by inner-sphere complexation in a rate-determining step. The above equation can be rearranged to give.

$$
\mathrm{k}_{0}{ }^{-1}=\frac{\left[\mathrm{H}^{+}\right]}{\mathrm{kK}}+\frac{1}{\mathrm{k}}
$$

Figure 4 illustrates the plot of $\mathrm{k}_{\mathrm{o}}^{-1}$ vs. $\left[\mathrm{H}^{+}\right]$where straight lines with non-zero intercepts were obtained. The values of $\mathrm{k}$ and $\mathrm{K}$ at various temperatures were calculated from the intercepts and slopes of the linear relationships and are listed in Table 3 . The values of $\mathrm{K}$ obtained are in good agreement with the reported value in the literature $\left(\mathrm{pK}_{\mathrm{a}}=3.89\right)$ [14].

Table 3 also included the entropy and enthalpy of activations. The positive value obtained for $\Delta S^{*}$ confirmed that the rate- determining step is the release of water molecule from the coordination shell of the chromium (III). For the water exchange reaction of $\mathrm{Cr}\left(\mathrm{H}_{2} \mathrm{O}\right)_{5} \mathrm{OH}^{2+}$, a value for $\Delta \mathrm{H}^{*}=110 \mathrm{k} \mathrm{Jmol}^{-1}$ and $\mathrm{k}=$ $5.0 \times 10^{-3} \mathrm{~s}^{-1}$ at $50^{\circ} \mathrm{C}[21]$. These values for $\Delta \mathrm{H}^{*}$ and $\mathrm{k}$ are in good agreement with the values obtained in the present study where values of $104 \mathrm{kJmol}^{-1}$ and $2.41 \times 10^{-3} \mathrm{~s}^{-1}$ at $50^{\circ} \mathrm{C}$ were obtained. Nearly comparable values of $\Delta \mathrm{H}^{*}$ and $\mathrm{k}$ with that obtained for water exchange reaction show an $\mathrm{I}_{\mathrm{d}}$ path for the reaction involving $\left[\mathrm{Cr}\left(\mathrm{H}_{2} \mathrm{O}\right)_{5} \mathrm{OH}\right]^{2+}$. 
Table 3 Rate constants and activation parameters for the reaction of $\mathrm{Cr}$ (III) ion with DTPA.

\begin{tabular}{ccc}
\hline Temperature $\left({ }^{\mathbf{0}} \mathbf{C}\right)$ & $\mathbf{1 0}^{\mathbf{3}} \mathbf{k}\left(\mathbf{s}^{\mathbf{- 1}}\right)$ & $\mathbf{1 0}^{\mathbf{4}} \mathbf{K}\left(\mathbf{m o l ~ L}^{-\mathbf{1}}\right)$ \\
\hline 35 & 0.75 & 0.85 \\
40 & 1.28 & 1.00 \\
45 & 1.53 & 1.95 \\
50 & 2.41 & 3.43 \\
$\Delta \mathrm{H}^{*}=104 \mathrm{~kJ} \mathrm{~mol}^{-1}$ & & \\
$\Delta \mathrm{S}^{*}=14 \mathrm{JK}^{-1} \mathrm{~mol}^{-1}$ & & \\
\hline
\end{tabular}

\section{References}

1) Anderson RA., 1993: Essential and Toxic Trace Elements in Human Health and Disease edn. WileyLiss, New York, 221-234.

2) Anderson RA., 1995: J Adv Med 8:37.

3) Andrew PK, Hong, Li C, Banerji SK, Wang Y., 2002: J Hazard Mater B; 94: 253-272.

4) Pastor J, Aparicio AM, Gutierrez-Maroto A, Hernandez A., 2007: Sci Total Environ; 378:114118.

5) Ohlenschlager L, Schieferdecker $H$, Schmidt-Martin W., 1978: Health Phys;35: 694-699.

6) Andrews FJ, Morris CJ, Kondratowicz G, Blacke DR., 1987: Ann Rheum Dis; 46:327-333.

7) Voest EE, Vreugdenhil G, Marx JJ., 1994: Ann Intern Med;120:490-499.

8) Kabir-ud-Din, Khan Z , Rafiquee ZA., 1996: J Chem Res Synop; 6: 308.

9) Pompa D, Gauri SD., 1993: Transit Met Chem;18: 353-355.

10) Kabir-ud Din, Khan GJ., 1990: Transit Met Chem;15: 39-42.
11) Zhitkovich A, Voitkun V, Costa M., 1996: Biochemistry; 35(22): 7275- 82.

12) Anis SS., 1999: Transit Met Chem; $24: 152$.

13) Anis SS., 2001: Mater Chem Phys; 72: 88-92.

14) Basolo F, Pearson RG., 1958: Mechanism of Inorganic Reactions- A Study of Metal Complexes in Solution. Wiley, p. 32.

15) Ali SI, Sharma S, Khan Z., 1996: Transit Met Chem; 21:222-225.

16) Thakur P, Mathur JN, Moore RC, Choppin GR., 2007: Inorganica Chim Acta; 360: 3671-3680.

17) Inciguerra VV, Bucci R, Marini F, Napoli A., 2006: J Therm Anal Calorim; 83: 475-478.

18) Bucci R, Magri AD, Magri AL, Napoli A., 2000: Polyhedron; 19: 2421-2425.

19) Gupta KS, Gupta YK., 1984: J Chem Educ; 61: 972978.

20) Rizkalla EN, Choppin GR., 1983: Inorg Chem; 22: 1478-1482.

21) Swaddle TW., 1974: Coord Chem Rev; 14: $217-268$. 